\title{
ENHANCING HALAL PROCUREMENT PRACTICE AMONG HOTEL IN MALAYSIA
}

\author{
Sara Shakira Binti Shari \\ Department of Admin Management and Human Resource \\ Faculty of Business and Accountancy, University of Selangor, Shah Alam, Malaysia \\ E-mail: sarashakira.shari@gmail.com \\ Muzairihana Binti Mohd Moid \\ Department of Admin Management and Human Resource \\ Faculty of Business and Accountancy, University of Selangor, Shah Alam, Malaysia \\ E-mail: hana84@unisel.edu.my \\ Kamisah Binti Supian \\ Department of Business Management and Sports Industry \\ Faculty of Business and Accountancy, University of Selangor, Shah Alam, Malaysia \\ E-mail: kamisah@unisel.edu.my \\ Anora Shaliaty Binti Suhaimi \\ Department of Business Management and Sports Industry \\ Faculty of Business and Accountancy, University of Selangor, Shah Alam, Malaysia \\ E-mail: norashasha5@gmail.com
}

\begin{abstract}
The demand for halal products has increased significantly throughout the world, either from Muslims themselves or non-Muslim communities. This phenomenon is due to an increasing concern for health as they believe that halal food has better cleanliness and safety. Few studies have shown that the supply chain plays a crucial role in ensuring that the products are halal compliant and that procurement is one of the main branches. In the hotel industry, the procurement department is responsible for ensuring that raw materials are arranged, purchased, delivered, and consumed effectively. Transparency, supplier engagement, and risk management are three elements that are highlighted matters in the hotel industry. Previous studies have shown that these three elements have a significant role in enhancing procurement practice in organisations. This paper focuses on the elements and effectiveness of halal procurement practises among Malaysian hotels. This study also aims to help companies evaluate their halal procurement practises and develop effective strategies to ensure that food products follow halal guidelines that ultimately enhance business performance.
\end{abstract}

Keywords: Halal Procurement, Halal Practice, Transparency, Supplier Engagement, Risk Management.

\section{INTRODUCTION}

The demand for more international travel necessitates revenue planning that focuses on the hotel. In supporting global economic growth, governments are allowing emerging economies to offer 
more open borders. It is an essential component of the rise in tourism and hospitality (Agyapong et al., 2018). Tourism is one of the most significant services sectors in Malaysia's GDP, accounting for $15.9 \%$ of it, where domestic tourists spent a total of RM92.6 billion and foreign tourists spent RM89.4 billion in 2019 (Ministry of Finance Malaysia, 2021). Besides, hotel travel is one of the fastest-growing sectors of the entire economy, and it is considered a subsidiary of the travel industry (Zeka, 2018). Halal hospitality and tourism have emerged as a rising sector of interest worldwide. As a result, tourism and travel are at the forefront of academic study (El-Gohary, 2020). The development level in halal tourism has been high, but Muslim-oriented hotels have fallen behind. Only 422 of the total 4,691 hotels are registered with halal food, according to JAKIM. Overall, this was just over 9.5\% of the industry (Razalli, 2018). As a new way of measuring consumer and quality assurance, halal creates new standards (Yusoff et al., 2017). For non-Muslims, food choice does not depend on halal only; it applies to culture as well. It shows good taste, well-being, and devotion to the product's resources (Zulfakar et al., 2017). Businesses, as well as the food, have to be halal approved. Regardless of whether it was acquired according to halal guidelines, every service and product should be verified as halal (Razalli, 2018). Also, managing the customer relationship is a necessary element in the hotel industry, so businesses must do it effectively and efficiently. The customers' expectations and buying behaviour are inextricably linked; acquiring knowledge is therefore crucial for the company's business strategy (Yasir et al., 2020).

Existing studies mainly focus on the halal supply chain from the manufacturer or food industry viewpoints, and little research is conducted on procurement or purchasing (Tieman et al., 2020). This paper is a preliminary study that aims to discuss halal procurement practices among hotels in Malaysia and how those elements assisted in improving business performance. This study acts as a basis for future research, and it is targeting to benefiting our hotel sectors and halal industry altogether (Ibrahim et al., 2020).

\section{Halal Concept}

\section{LITERATURE REVIEW}

The term halal encompasses everything Muslims' concerns, including their dietary practices. Islamic dietary law states that foods generally are permitted, except for those specifically referenced in the Quran and Hadith. Any forbidden or prohibited in the religious law is referred to as haram (Khan et al., 2019). Many aspects of Muslim life are following Islamic law. Accordingly, halal includes both consumables and services and products and dealings with clients, commerce, trades, and finances. Halal food is designed to protect Muslim from fraud and mislabeling (Zul Ariff Abdul Latiff et al., 2018). Practically, Muslims must ensure that the halal rules of conduct are observed in every instance of their lives. The extent to which individuals consider and follow the Syariah guideline depends on themselves. However, $70 \%$ of Muslims worldwide cohere to some of the rules associated with halal foods (Ahmad et al., 2018). According to DinarStandard (2019), more than $60 \%$ of the entire Islamic economy is in the halal food and beverage sector. By 2024, Muslims are expected to spend approximately US\$2 trillion compared to US\$1.4 trillion in 2018. The status of food halalness is managed by a shariah institution that usually appointed by the government (Novianti et al., 2020). In their paper, Maman et al. (2017) discussed the four phases of halal evolution; Muslim company, supply chain, value chain, and overall halal economy. The halal system in Muslim businesses relies entirely on trust. The attitude of trustworthiness deserves our attention when involved in a lawful activity that is pious. In the halal product, the independent halal certification body's assurance is 
tied to the product's certification process. A halal chain's integrity goes as far up as transportation, transportation of purchased ingredients, and as far as storage. The creative challenge of Islamic values is applied throughout the halal value chain. Among others is a concept related to takaful and branding. In another example, this would include takaful-adoption, green adoption and environmental marketing concepts, applying green labelling techniques, and ecological benefits such as waste minimisation (Tieman \& Ghazali, 2013).

\section{Operational Performance}

Al-Sa'di et al. (2017) note that unique operational capabilities produce an output different from any other firm in the market. Stable operations reflect quantifiable characteristics, such as unchanged results and accurate processes to handle pressure (Bani, 2021). The performance deals with a wide aspect of a project to help achieve organisational goals and the organisation's overall objective (Baharuddin \& Ismail, 2018). Without proper streamlining, the business may lose its value as a producer or supplier of hospitality and its benefit to customers or stakeholders. These major challenges keep hotel managers on their toes, requiring constant and flexible adaptation and higher profits for quality in an always-changing market while responding to market expectations and delivering better-grade products in the regularity of supply and demand (Alsetoohy \& Ayoun, 2018). The effect of performance of operational systems in food production and textile production has been debated throughout history, whether among critics or advocates (Iqbal \& Iqbal, 2018). In several studies, halal certification had been found to lead to higher market share and enhanced performance (Giyanti \& Indriastiningsih, 2019). Studies have shown that various definitions have recommended implementing halal standards to favour a financial and operational turnaround (Ab Talib et al., 2017). A performance criterion is a reflection of an organisation's success. It can, for example, be used to measure the market's performance, customer satisfaction, operational, or financial success.

Nevertheless, it's proven that supply chain competition takes place between different entities. Thus, it is imperative to include all parties and measure supply chain performance. Businesses will be more efficient and better managed due to a well-maintained supply chain (Basu et al., 2017; Shahbaz et al., 2018). Historically, few components and practices, such as brand, distribution, have been linked to hotel profits. But the new and sophisticated approaches to linking intangibles to results are creating a clearer picture of how important they are to the overall profits of the hotel (Hinson et al., 2017; Alnawas \& Hemsley-Brown, 2019; Panno, 2019).

\section{Halal Procurement Practice}

Purchase controls have been in question for decades because inefficient processes and procedures implementing a purchasing function created disparities and inequitable penalties (Kakwezi \& Nyeko, 2010). The procurement department must be part of the company's organisation for a smoothly functioning supply chain. Procurement services are essential for industries because they have to acquire raw materials and help to use them and plan and supply. Because of the recent acquisition and quality control influx, this department has additional control and activities. Businesses need to determine the total acquisition and maintenance costs and indirect costs associated with acquiring and retaining a customer life (Ibrahim et al., 2020). The procurement process was studied by Bratt et al. (2012) as including tasks such as defining essential requirements. In terms of marketing, assessing the market, purchasing, and negotiating with vendors, it has a complete mix of activities. It is crucial in purchases, plans for acquisitions, 
policies, and processes. Based on their research, Nor et al. (2016) concluded that purchasing is necessary to establish and manage the upstream supply chain, assess and process sources, manage vendors, and verify suppliers and distribution.

Halal purchasing is a recent academic topic of study initiated by Tieman and Ghazali (2013). They discuss how halal affects the procurement strategy and procurement process (Tieman et al., 2020). Rasi et al. (2017) defined halal procurement as the buying practises that foster the preservation of halal integrity throughout the supply chain. A thorough understanding of the various stages of the halal supply chain is needed to make sure food items do not become anything that is forbidden under Islamic law. Halal depends on every part of the supply chain. Accordingly, a business must conduct rigorous supply chain validation to protect its halal legitimacy from the view of its clients (Muhamed et al., 2020). There are various ways to increase productivity and efficacy, as stated by Shahbaz et al. (2018).

\section{Transparency}

Existing studies mainly focus on transparency in the banking or financing field, but it is almost non-existent within the halal supply chain scope. In their paper, Raja Hisham et al. (2019) discussed that transparency aligns with Islamic values. According to Hamdan et al. (2018), traceability and transparency are completely bound, so delivery is more reliable with halal products. As halal food must follow the halal guideline with the absence of unsafe substances, non-halal ingredients must not be permitted in halal food. Many aspects of the entire production cycle are given importance because of the economies of scale. From the initial selection to ultimate processing, many different raw materials, including prepackaging, storage, and transportation, are considered (Novianti et al., 2020). Transparency helps reduce the legal exposure or responsibilities the firm may have in the event of an accident or injury, and it frequently goes hand in hand with openness and accessibility to everyone involved. Over the years, the combined meaning of transparency and flow, concept of openness, has also expanded to encompass the means of creation. When early commentators used the term transparent, they had in mind a direct, valid, and obvious state without vulnerability. Transparency depends on both the context and setting in which it is used (Hamdan et al., 2018). Wittig (2005) saw transparency as involving both parties' ability to recognise each other's ability to comprehend the exact terms and steps of the transaction (Obura, 2019). Also, traceability and cooperation from all relevant parties are required for a transparent and accountable halal supply chain. Halal assurance traceability is critical for the success of the system. Risk contamination can be reduced through product traceability, which is crucial in the halal food industry. By understanding the effects and consequences of each component, customers can perceive the full scope of the product (Abd Rahman et al., 2017).

Moreover, there is almost no way to know what food ingredients were used, if any harm was done to animals, or if it was harvested in an environmentally responsible manner during the production process without full disclosure. To be transparent, organisations must develop new bidding language and organisational practices like improved record keeping. While technical advances can help with this, many behaviours can't be solved by technology alone (Farnsworth et al., 2019). Besides, the inability to ensure adequate information and tracking in food procurement can create customers' distrust and lead to serious health problems. In 2014, consumption of melamine-laced milk had resulted in 300,000 babies becoming sick and six fatalities. As a result of the bad press, the Chinese government tightened its regulation of food 
additives. However, the underlying issue can never be entirely resolved, as this case proves (Astill et al., 2019).

\section{Supplier Engagement}

Good relationships between suppliers and customers result in the best operational performance. When the dependency level increases, it can be reasonably assumed that the need for collaboration grows (Salam, 2017). Studies by Stevens (2011), as cited by Kiarie (2017), mentioned that results would be influenced by the kind of relationships an organisation has with its suppliers. An organisation's type of relationship management method will impact every facet of the company in one way or another (Kiarie, 2017). Companies in hospitality must cooperate to enhance their performance. Previous research found that improved productivity and cost reduction can be helped by better aid ( $\mathrm{Ku}$ et al., 2020). The relationship between buyer and supplier should strengthen halal food production (Azmi et al., 2021). The recognition of halal on supplier engagement practices reflects the crucial role in halal procurement practice (Sheikh \& Khan, 2018). Supian \& Rashid (2018) explained the importance of suppliers credibility in the supply chain process as it helps maintain the food is halalan-thoyyiban. Accordingly, the supplier's trustworthiness is intimately connected with the effectiveness of the business.

\section{Risk Management}

In the supply chain, one of the key responsibilities is risk management. Since the strategic alliances increase global supply-chain risk, businesses have an increased risk and uncertainty. Companies need to employ supply-chain mitigation strategies (Moazzam et al., 2018) and create a risk system to find and manage higher levels of efficiency (Munir et al., 2020). The inadequacy of risk analysis can cause disruptions in supply flow. The impact of risk on business can be primary or short-term, ranging from tolerable to severe (Mohamad \& Backhouse, 2019).

The negligence during producing food that conforms to halal standards can lead to the failure of the halal supply chain, and eventually, this will lead to the existence of a risk to Toyibb's. Despite the significance of risk management in both conventional and halal trade, few studies have been done, and even fewer articles were written (Khan et al., 2020).

Quality is vital because raw materials integrity is helping to guarantee the health and safety of materials used in production and, second, to keep unreliable suppliers from having an impact on the manufacturing process before it begins. The raw material aspect includes integrity in the following four fundamental categories: safety, innocence, purity, and quality. The objective of industrial process control is to prevent contamination throughout the entire manufacturing system and facility. For the manufacturer's actions, procedures should encompass all forms of quality control to safeguard halalness (Usman, 2020). The 2014 Cadbury chocolate issue prompted the importance of risk management. It was subsequently discovered that there is no porcine DNA in the factory, and it might be exposed after leaving the factory. This issue shows that risk management is highly crucial, starting from the early stage of procuring raw ingredients until reaching the consumer (Lee et al., 2019). Management of halal risks should constantly be optimised. However, to minimise cost impact, risk management should be justified according to suitability. Businesses should manage those risks according to supply chain scenarios such as product characteristics, supply chain structure, and brands (Tieman, 2017).

\section{METHODOLOGY}

This preliminary study will adopt the quantitative study method, where the questionnaire is designed to explore the elements of halal procurement practices and their relationship with 
operational performance. The questionnaire will be distributed to procurement personnel and halal executive in hotels. This study targeted hotels in Klang Valley due to the numbers of 3,4 and 5 stars hotels available. As this study will focus on the organisation, each hotel will only be given one set of questionnaire.

\section{CONCLUSION AND POLICY RECOMMENDATION}

Halal and hotel industry contributed to the country's economic GDP significantly (Ministry of Finance Malaysia, 2021); thus, the outcome of this study will enhance the performance of related fields. Halal supply chain management or halal procurement in specific is still in developing stages. Organisations are encouraged to develop an in-depth understanding of halal (Rasi et al., 2017). Previous literature concluded that halal certification and practices provide significant positive outcomes on a company's performance (Ab Talib et al., 2017). This paper identified halal procurement practices and their relationship with operational performance based on previous studies and literature reviews. Academics and businesses will be benefited from this study. In an academics context, dimensions have been identified to indicate how those elements can be effectively measured. In a business professional's context, the association between the variables will be tested and validated, which will improve operations of the Malaysian hotel industry to be more effective and efficient. This investigation will assist the organisation in improving its operational performance. Also, this study targets to be the basis of future research. The development of analyses is expected to benefits the Malaysian hotel industry and halal industry.

\section{REFERENCES}

Ab Talib, M. S., Ai Chin, T., \& Fischer, J. (2017). Linking Halal food certification and business performance. British Food Journal, 119(7), 1606-1618. https://doi.org/10.1108/BFJ-012017-0019

Abd Rahman, A., Singhry, H. B., Hanafiah, M. H., \& Abdul, M. (2017). Influence of perceived benefits and traceability system on the readiness for Halal Assurance System implementation among food manufacturers. Food Control, 73, 1318-1326. https://doi.org/10.1016/j.foodcont.2016.10.058

Agyapong, A., Mensah, H. K., \& Ayuuni, A. M. (2018). The moderating role of social network on the relationship between innovative capability and performance in the hotel industry. International Journal of Emerging Markets, 13(5), 801-823. https://doi.org/10.1108/IJoEM-11-2016-0293

Ahmad, A. N., Ungku Zainal Abidin, U. F., Othman, M., \& Abdul Rahman, R. (2018). Overview of the halal food control system in Malaysia. Food Control, 90, 352-363. https://doi.org/10.1016/j.foodcont.2018.02.035

Al-Sa'di, A. F., Abdallah, A. B., \& Dahiyat, S. E. (2017). The mediating role of product and process innovations on the relationship between knowledge management and operational performance in manufacturing companies in Jordan. Business Process Management Journal, 23(2), 349-376. https://doi.org/http://dx.doi.org/10.1108/BPMJ-03-2016-0047

Alsetoohy, O., \& Ayoun, B. (2018). Intelligent agent technology: the relationships with hotel food procurement practices and performance. Journal of Hospitality and Tourism Technology. https://doi.org/https://doi.org/10.1108/JHTT-04-2017-0028

Astill, J., Dara, R. A., Campbell, M., Farber, J. M., Fraser, E. D. G., Sharif, S., \& Yada, R. Y. (2019). Transparency in food supply chains: A review of enabling technology solutions. 
Trends in Food Science and Technology, 91, 240-247. https://doi.org/10.1016/j.tifs.2019.07.024

Azmi, F. R., Musa, H., Chew, B. C., \& Jagiripu, I. P. (2021). Supply risk management: A case study of halal food industry in Malaysia. Uncertain Supply Chain Management, 9(2), 501-512. https://doi.org/10.5267/j.uscm.2021.1.001

Baharuddin, S. A., \& Ismail, R. M. (2018). Halal compliance impact on organisational performance: The role of religiosity. International Journal of Supply Chain Management, 7(5), 455-460.

Bani, J. S. (2021). Uncertain Supply Chain Management The moderating role of lean operations between supply chain integration and operational performance in Saudi manufacturing organisations. Uncertain Supply Chain Management, 9, 169-178. https://doi.org/10.5267/j.uscm.2020.10.004

El-Gohary, H. (2020). Coronavirus and halal tourism and hospitality industry: Is it a journey to the unknown? Sustainability (Switzerland), 12(21), 1-26. https://doi.org/10.3390/su12219260

Farnsworth, L. D., Delwiche, A., \& Mckinney, C. (2019). The Good Food Purchasing Program : A Policy Tool for Promoting Supply Chain Transparency and Food System Change. In Institutions as Conscious Food Consumers. Elsevier Inc. https://doi.org/10.1016/B9780-12-813617-1.00005-8

Giyanti, I., \& Indriastiningsih, E. (2019). Impact of Halal Certification on The Performance of Food Small Medium Enterprises. Jurnal Ilmiah Teknik Industri, 18(2), 116-123. https://doi.org/10.23917/jiti.v18i2.7242

Hamdan, F. A., Nasir, S., \& Jaafar, H. S. (2018). Evaluating Transparency in Halal Trade Facilitation. Advances in Transportation and Logistics Research, Volume 1(2016), 516527. http://proceedings.itltrisakti.ac.id/index.php/ATLR/article/view/49/58

Ibrahim, S. Z., Lahap, J., Nazlan, N. H., Ariffin, H. F., \& Mohd Said, N. (2020). Developing A Procurement Framework for the Malaysian Hospitality Industry: A Preliminary Study. ESTEEM Journal of Social Sciences and Humanities, 4, 10-18. http://ejssh.uitm.edu.my/

Iqbal, J., \& Iqbal, Z. (2018). Stochastic Procurement Its Major Determinants and Their Impact on Operational Performance of Textile Firms : A Case Study of Faisalabad Pakistan Zafar Iqbal. 2(2), 164-182.

Khan, S., Khan, M. I., Haleem, A., \& Jami, A. R. (2019). Prioritising the risks in Halal food supply chain: an MCDM approach. Journal of Islamic Marketing. https://doi.org/10.1108/JIMA-10-2018-0206

Kiarie, J. W. (2017). The Influence of supplier relationship management practices on operational performance of large manufacturing organisations in Kenya [Strathmore University]. http://su-plus.strathmore.edu/handle/11071/5586

Ku, E. C. S., Hsu, S.-F., \& Wu, W.-C. (2020). Connecting supplier - supplier relationships to achieve supply chain performance of restaurant companies. Journal of Hospitality and Tourism, 3(3), 311-328. https://doi.org/10.1108/JHTI-10-2019-0113

Lee, H. Y., Hwang, H. J., \& Kim, D. H. (2019). Issues of halal supply chain management: Suggestion for Korean traders. Journal of Korea Trade, 23(8), 132-144. https://doi.org/10.35611/jkt.2019.23.8.132

Ministry of Finance Malaysia. (2021). Economic outlook. In Percetakan Nasional Malaysia Berhad. www.treasury.gov.my

Moazzam, M., Akhtar, P., Garnevska, E., \& Marr, N. E. (2018). Measuring agri-food supply 
chain performance and risk through a new analytical framework: a case study of New Zealand dairy. Production Planning and Control, 29(15), 1258-1274. https://doi.org/10.1080/09537287.2018.1522847

Mohamad, N., \& Backhouse, C. (2019). A framework for the development of Halal food products in Malaysia. Loughborough's Research Repository. http://iieom.org/ieom2014/pdfs/151.pdf

Novianti, D., Arkeman, Y., Almunawar, M. N., \& Haditjaroko, L. (2020). Designing a Transparent Distributed Systems for Halal Supply Chains Using Blockchain Technology. Journal of Business \& Economic Analysis, 3(2), 151-170. https://doi.org/10.36924/sbe.2020.3204

Obura, C. O. (2019). Role of Integrity in Enhancing Effective Procurement Practice in Kenya Bureau of Standards. European Journal of Business and Strategic Management, Vol.4(Issue 2), pp 77-86. https://iprjb.org/journals/index.php/EJBSM/article/view/864/990

Rasi, R. Z., Masrom, N. R., Omar, S. S., Ahmad, M. F., \& Sham, R. (2017). Designing Halal Supply Chain: Malaysia's Halal Industry Scenarios. MATEC Web of Conferences, 135, 00040. https://doi.org/10.1051/matecconf/201713500040

Razalli, M. R. (2018). Managing Halal certification supply chain: Determinants success factors framework for a hotel performance. International Journal of Supply Chain Management, 7(1), 149-154.

Salam, M. A. (2017). The mediating role of supply chain collaboration on the relationship between technology, trust and operational performance: An empirical investigation. Benchmarking, 24(2), 298-317. https://doi.org/10.1108/BIJ-07-2015-0075

Sheikh, O. A., \& Khan, M. N. (2018). Exploring the Halal Supply Chain in Pakistan. International Conference on Contemporary Issues in Business \& Economics, 354-362.

Supian, K., \& Rashid, N. A. (2018). The Role of Supplier, Top Management and Government in Halal Practices Integrity of Malaysian Food Business. International Journal of Asian Social Science, 8(8), 549-559. https://doi.org/10.18488/journal.1.2018.88.549.559

Tieman, M. (2017). Halal risk management: combining robustness and resilience. Journal of Islamic Marketing.

Tieman, M., \& Ghazali, M. C. (2013). Principles in halal purchasing. Journal of Islamic Marketing, 4(3), 281-293. https://doi.org/10.1108/JIMA-01-2012-0004

Tieman, M., Zakaria, Z., Sulaiman, A., \& Ramli, S. Q. (2020). Halal procurement strategy in the food industry: a focus group discussion. International Journal of Islamic Marketing and Branding, 5(3), 167-180. https://doi.org/10.1504/ijimb.2020.10035279

Yasir, M. A., Amir, A. M., Maelah, R., Hafiz, A., \& Nasir, M. (2020). Establishing Customer Knowledge Through Customer Accounting in Tourism Industry: A Study of Hotel Sector in Malaysia. Asian Journal of Accounting and Governance, 14.

Yusoff, T., Abdul Razak, I., \& Abdul Aziz, A. (2017). Halal Integrated Logistic Management System: Lesson Learnt from Malaysian Industries. First International Halal Management Conference, August, 0-17. https://www.researchgate.net/publication/321069012

Zeka, K. (2018). Hotel Industry Development in Kosovo Hotel Industry Development in Kosovo Honors Project.

Zul Ariff Abdul Latiff, Fatin Aqilah Dzulkifli, Noor Iffa Haniz Zakaria, Nor Sahira Edi, Nur Fraihin Aman Zuria, Siti Nursyahirah Mohamad Radzip, \& Nursalwani Muhamad. 
(2018). The Application of Online Halal Label Among Food Manufacturer Behavior Toward the Halal Label System in Malaysia. Canadian Social Science, 14(8), 55-60. https://doi.org/10.3968/10484

Zulfakar, M. H., Chan, C., \& Jie, F. (2017). Institutional forces on Australian halal meat supply chain (AHMSC) operations. Journal of Islamic Marketing. https://doi.org/10.1108/JIMA-01-2016-0005

\section{Copyrights}

Copyright for this article is retained by the author(s), with first publication rights granted to the journal. This is an open-access article distributed under the terms and conditions of the Creative Commons Attribution license (https://creativecommons.org/licenses/by/4.0) 